\title{
LEGAL FRAMEWORK OF YOUTH UNEMPLOYMENT AND ENTREPRENEURSHIP REGULATION IN LATVIA
}

\author{
LİVA GRIN̦EVIČA ${ }^{1}$, BAIBA RivŽA²
}

Latvia University of Agriculture, Faculty of Economics and Social Sciences (Latvia)

\begin{abstract}
Youth unemployment, especially long-term unemployment, is one of Europe's most pressing problems to deal with. In the current economic and financial crisis, the lack of job opportunities has affected young people more than any other group in society. Consequently, young people are faced with social problems, they cannot successfully integrate into the labour market to ensure their future stability and build their life in the future. The paper deals with legal and institutional frameworks of youth unemployment and social integration as well as makes a discussion on the survey results regarding young people integration into the labour market. It is important to identify the key regulative framework of legislative and planning documents and to understand their importance with regard to youth unemployment regulation and a contribution to unemployment reduction.

KEY WORDS: youth's integration, youth unemployment, legal framework of unemployment.
\end{abstract}

JEL CODES: E24, J64

DOI: http://dx.doi.org/10.15181/rfds.v14i3.859

\section{Introduction}

The paper examines the legal and institutional frameworks of unemployment regulation in Latvia as well as the available support instruments for promoting entrepreneurship and self-employment. A potential legal framework of entrepreneurship and self-employment for Latvia was developed and the most appropriate legal regulation of unemployment was identified (Figure 1).

The research object is the youth's long-term unemployment regulation as an expression of successful youth's integration in the labour market.

The research aim is to present the youth's unemployment regulation in the Republic of Latvia in the context of European planning documents.

The research methods. General research methods: an analysis of legal acts, laws and documentation, an analysis of scientific literature and sources, comparative and logical analysis, theoretical modelling and a discussion of the research results were employed to achieve the aim.

1 Līva Grineviča - PhD student, Latvia University of Agriculture, Faculty of Economics and Social Sciences, Regional Economics

E-mail: Liva_g2@inbox.lv

Tel.: + 37128244527

2 Baiba Rivža - Dr. habil. oec., Professor of Latvia University of Agriculture, Faculty of Economics and Social Development; Academician of the Latvian Academy of Sciences

E-mail.: baiba.rivza@llu.lv

Tel.: + 37129254469 
This paper will show only a part of the authors' research results. The research of opinions of and possibilities for young people and their integration into the labour market in Latvia has just begun, and further results of the research will be possible to present in future scientific research papers by the authors.

The following research tasks are set to achieve the aim:

- To define the youth unemployment problem according to legal acts, laws and other documentation.

- To analyse Latvia's strategic planning documents as an aspect of youth unemployment support.

- To understand the young people's view of the situation in the labour market.

\section{CONSTITUTION OF THE REPUBLIC OF LATVIA}

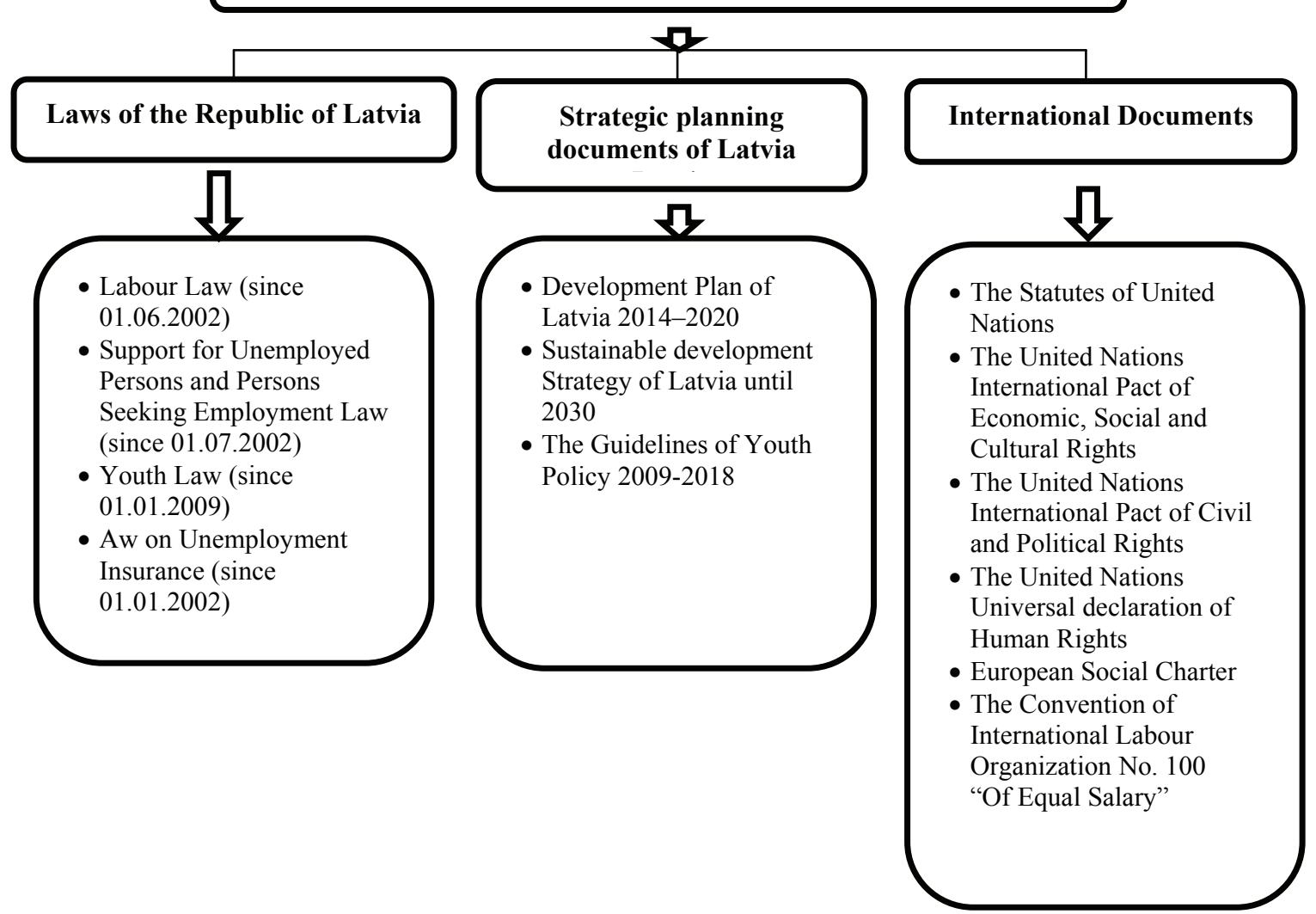

Source: authors' construction

Fig. 1. Hierarchy of the legal framework of youth unemployment in the Republic of Latvia

Research results and discussion

1. Legal framework of youth unemployment regulation in Latvia

The law "International Contracts of the Republic of Latvia", Article 13, requires that if an international agreement is approved by the Saeima ${ }^{3}$, and there are other rules set in the legislation of the Republic of Latvia, the rules of international contracts are applied. This means that if there is contradiction between the international and national documents, international document standards are applied. For an individual faced with a problem, it is important to remember this aspect, because it would be helpful to get in-depth information of the applicability of international documents (International Contracts of...).

3 The Parliament of the Republic of Latvia. 
The existing Labour Law of Latvia was adopted on the $20^{\text {th }}$ June of 2001 and came into force on the 1 st June of 2002, replacing the Code of Labour Law which was effective from the $1^{\text {st }}$ October of 1972. Compared with the previous law, the Labour Law provided significant differences between them.

On the $1^{\text {st }}$ June of 2002, the "Support for Unemployed Persons and Persons Seeking Employment Law" was passed, with the purpose to provide support for unemployed persons, persons seeking employment and persons subject to the risk of unemployment in order to facilitate their ability to compete in the labour market.

According to the Law's Section 2, this Law determines the active employment measures and preventative measures for unemployment reduction intended for unemployed persons, persons seeking employment and persons subject to the risk of unemployment, the competence of the State and local governments in the implementation of these measures, as well as the status, rights and duties of an unemployed person and person seeking employment. The following persons have the right to receive the support specified in this Law: unemployed persons, persons seeking employment and persons subject to the risk of unemployment (Support for Unemployed..., 2002).

The purpose of active employment measures is to put into effect the labour market policy in order to reduce unemployment and to facilitate an increase in the economic activity of inhabitants, in particular to:

- motivate unemployed persons, persons seeking employment and economically inactive inhabitants to seek employment more actively;

- promote the formation of a labour force that is trained and capable of adjusting to the conditions of the labour market;

- promote an increase in the competitiveness of the individual; and

- promote the creation of equal opportunities for persons who wish to enter the labour market (Support for Unemployed..., 2002).

The Labour Law's Section 7. "Principle of Equal Rights" includes important information, where one of the most important issues is the non-discriminatory treatment, for example, "Everyone has an equal right to work, to fair, safe and healthy working conditions, as well as to fair work remuneration. The rights shall be ensured without any direct or indirect discrimination - irrespective of a person's race, skin colour, gender, age, disability, religious, political or other conviction, ethnic or social origin, property or marital status, sexual orientation or other circumstances" (Labour Law, 2001).

Also the Labour Law's Section 7. "Principle of Equal Rights" draws attention to fair working conditions and wages (Labour Law with..., 2010) which is also highlighted in the International Planning Documents such as the European Convention of Human Rights, the Pact of United Nations of Civil and Political Rights etc. (United Nations Declaration...; International Covenant on...).

"The Constitution of the Republic of Latvia", Chapter VIII "Fundamental Human Rights", mentions that "all human beings in Latvia shall be equal before the law and the courts. Human rights shall be realised without discrimination of any kind" (The Constitution of...).

According to International Labour Market Convention No. 11, the terms "employment" and "position" include vocational training, employment and access to certain posts, as well as the terms and conditions of employment without individuals' discrimination (Convention No. 11 of...). The Constitution, by its nature, could not provide less protection of fundamental rights protection than it is envisaged in any law of the international human rights. A different conclusion would be at a conflict with the Constitution, Article 1, regarding the legal state idea, because the rule of human rights has the highest value in terms of the main forms of expression and fundamental freedoms in the country. It should also be noted that the Constitution may also provide more extensive protection of fundamental rights than the law of international human rights (Labour Law with..., 2010).

The authors consider it is very important that important information on non-discriminatory attitude is included in the Labour Law - an employer can employ individuals based on their professional qualification and other skills required for the work. Although, according to recent international documents of human rights and also practice in the world's countries, the prohibition of discrimination extends to new manifestations of 
discrimination, thereby the scope of this principle is significantly expanded. It is important to pay attention to the long-term unemployed individual's discrimination, which is unreasonable and often, by employers, is shown as the main reason why individuals are not employed.

2. Strategic planning documents and international documents on the regulation of youth unemployment

It is important to mention the "National Development Plan of Latvia for 2014-2020" with regard to youth unemployment, in which strategic aims are defined clearly for identifying employment questions. The Plan's Article 26 "Employment" mentions that "Society recognises that social and regional inequality as well as inequality of opportunity can be reduced by a high level of employment where each individual strives towards productivity. Therefore, inclusive, sustainable and competitive economic development has a balanced growth of various sectors of the economy as its basis - which at once provides a sufficient number of jobs to match the existing skills of the population and offers new types of employment with a higher value added and remuneration" (National Development Plan..., 2012).

The Plan's Article 27 includes information on the individual's non-discrimination and the promotion of employment - "The unemployed have access to time bound, focused and relevant assistance from the state that encourages learning and returning to the labour market as soon as possible. State assistance is aimed at non-discriminatory treatment in the labour market, the acquisition and development of new competencies and skills and improving qualifications or requalification" (National Development Plan..., 2012).

The Development Plan's Article 28 highlights that "at work, people realise their interests and abilities and improve themselves professionally. Employment links them to the country in which they live and to other residents. Work is not merely a means of ensuring daily sustenance but also a method of self-actualisation, a way to forge and maintain social and civic ties for the Latvian population" (National Development Plan..., 2012).

The authors consider that it is important to develop a national economy with a competitive workforce; it is the reason why unemployed people need to reintegrate into society with support from the State Employment Agency and integration and social inclusion projects of the European Social Funds.

The International Covenant on Economic, Social and Cultural Rights, the Universal Declaration of Human Rights and the European Social Charter determine that everyone has rights to choose political status and everyone can freely pursue their economic, social and cultural development.

At international level, the rights of an individual are regulated by the "Charter of the United Nations" Chapter IX "International Economic and Social Co-operation", Article 55 defines that "with a view to the creation of conditions of stability and well-being which are necessary for peaceful and friendly relations among nations based on respect for the principle of equal rights and self-determination of peoples, the United Nations shall promote:

- higher standards of living, full employment, and conditions of economic and social progress and development;

- solutions of international economic, social, health, and related problems; and international cultural and educational cooperation;

- universal respect for, and observance of, human rights and fundamental freedoms for all without distinction as to race, sex, language, or religion (Charter of the United...).

The Charter of the United Nations is one of the most important international instruments that focuses on the prevention of an individual's discriminations, and it is binding for Latvia from 1991.

Importance of the International Labour Organization's (ILO) role. In 1951 Convention No.100 "Equal Pay" is one of the fundamental ILO conventions; in Latvia it is effective from the 27th January of 1993. The preamble to the ILO provides the measures to improve working conditions, included in the principle of equal pay for work of equal value (Specific Problems of...). 
"The Employment Equality Framework Directive (2000/78/EC)" is an European Union (EU) Directive, and a major part of EU labour law which aims to combat discrimination on grounds of disability, sexual orientation, religion or belief and age in the workplace. This Directive introduces with a general framework to ensure equal treatment between EU citizens regardless of their religion or beliefs, possible disability, age or sexual orientation as regards access to the profession or, for promotion, vocational training, working conditions and the approach to work or involvement in certain organizations (Council Directive, 2000).

The European Commission promotes dialogue between youth and policy makers in order to increase active citizenship, foster social integration, and ensure inclusion of the young in European Union policy development. These priorities form a core part of the "European Union Youth Strategy for 2010-2018", which has two overall objectives:

- to provide more and equal opportunities for young people in education and in the job market;

- to encourage young people to actively participate in society.

The Strategy proposes initiatives in eight fields of action:

- Education and training.

- Employment and entrepreneurship.

- Health and well-being.

- Participation.

- Voluntary activities.

- Social inclusion.

- Youth and the world (EU Youth Strategy...).

Policies to improve labour supply:

- A flexible labour market, and according to the situation, active labour market policies and lifelong learning activities.

- Improving the quality of jobs, labour market relations and occupational health and development of safety regulatory framework.

- The timely identification of labour market needs, development of labour market forecasting system and improving the relevant services and diversifying the forms of provision.

- Reducing undeclared work.

- Self-employment and entrepreneurship.

- Infrastructure and social care services and making them more accessible.

- An education reform, improving education programmes in accordance with the requirements of the labour market (Latvian National Reform...).

Employment and an individual's professional life play a vital role in ensuring equal opportunities for all individuals and contribute to the participation of citizens in the economic, social and cultural life. However, many cases of discrimination are observed in the labour market and employment.

All the measures mentioned above serve the ultimate purpose of creating an environment conducive to growth and job creation in the EU, because it is the only way to continue financing our way of life. Since the beginning of the crisis, the Commission has consistently called for growth-enhancing measures, which are at the heart of the Europe 2020 strategy. This growth must, however, be based on solid grounds; this is the reason why the Commission is acting to promote smart, sustainable and inclusive growth.

\section{Youth's integration into the labour market}

There are structural reasons, including lack of job opportunities, in particular in some regions, making it difficult for young people to fully integrate into labour markets. The crisis has exacerbated this youth unemployment challenge in many countries especially for disadvantaged groups. More than half of young 
men and women on the labour markets are now unemployed in some countries. Urgent action is required to provide more and better jobs for the young and avoid scarring effects both to young people and European economies and societies as a whole (Framework of Actions..., 2013).

To identify the young people's position on the situation regarding the employment possibilities in the labour market, the authors conducted a survey.

According to the survey results, of all respondents $(n=212)$, answers from females were 181, from males only 31 . The authors consider that it is explained by the fact that more women than men are studying in institutions of higher education. Also in Latvia, more women than men have higher education and professional degrees; it does not apply to industries where men are working, for example, information technology, engineering, electronics etc.

Most of the respondents were from Riga (58\%), $5 \%$ of them lived near Riga, $22 \%$ of all the respondents were from small towns, $4 \%$ were from Jelgava, $2.5 \%$ - Liepaja, $2 \%$ - Valmiera and rural areas, $1 \%$ - Daugavpils, Ventspils, $0.5 \%$ - Rezekne.

According to the results of the survey, $18.9 \%$ of the young people were only students, $33.5 \%$ were students who also worked, $39.2 \%$ of the respondents only worked and $8.5 \%$ were unemployed and also were not studying. The average age of respondents was 23 years. Based on it, the authors assume that a very high proportion of young people who took part in the survey only worked and were not studying. Of these answers, we can deduce that part of the respondents had faced various social distractions that affected their choice of studying.

According to the respondents' answers to the question "In what way did you find your current job?", $43.5 \%$ of them found a job by themselves by regularly sending their CV to Internet-based ads, a large part of them (39.6\%) answered that they found his/her job through friends and acquaintances, only $5.2 \%$ found a job while practicing within the studies, and then remained in the same job where got practice. Of all the respondents, $8.4 \%$ marked the answer "other" and answered that they were self-employed and started his/ her own entrepreneurship already. It is appreciated because it means that some of the students have begun to take an interest in their business development at least, and knowledge from the studies had been used for improving our country's economic situation.

Table 1. What kind of attitude you have encountered from employers in assessing your candidacy to the job before? $(n=212)$

\begin{tabular}{|l|c|}
\hline \multicolumn{1}{|c|}{ Type of answer } & $\begin{array}{c}\text { Result of student } \\
\text { answers (\%) }\end{array}$ \\
\hline $\begin{array}{l}\text { My candidacy was positively evaluated for the vacant position regardless of my experience and } \\
\text { level of education }\end{array}$ & $\mathbf{2 7 . 9}$ \\
\hline $\begin{array}{l}\text { I was given the opportunity to gain experience and to acquire the necessary skills for the execution } \\
\text { of the given position }\end{array}$ & $\mathbf{3 8 . 7}$ \\
\hline My competitiveness against more experienced applicants was negatively assessed & 15.7 \\
\hline $\begin{array}{l}\text { It was negatively assessed that I am a student } \\
\text { gegative attitude, I am in one of the risk groups of unemployment (for example, ethnicity, age, }\end{array}$ & 1.7 \\
\hline $\begin{array}{l}\text { Neutral attitude, I am in one of the risk groups of unemployment (for example, ethnicity, age, } \\
\text { gender etc.) }\end{array}$ & 4.2 \\
\hline Other answer & 5.5 \\
\hline
\end{tabular}

Source: authors' survey results

It was important to find out how long young people have been in search of work; according to the results of the survey, $50.7 \%$ of the young people answered that they were not searching for work. The authors explain this by the young people's desire to complete their studies and start their careers after university or 
college graduation. $18.3 \%$ of the youth were searching for work from 1 to 3 months, $15.5 \%-3$ to 6 months, $4.2 \%$ - could not find a job for 12 months and longer.

The authors consider that in Latvia it is important to include restrictions on employers as well as universities in national laws, like a special provision for young people to allow them to undergo practical training within their studies and develop conditions for entrepreneurs regarding further employment of young people after their graduation, if the young people during their practical training demonstrated and proved their ability and competitiveness within the company.

According to Table 1, answers to the question "What kind of attitude you have encountered from employers in assessing your candidacy to the job before?", $38.7 \%$ of the respondents answered positively that they got opportunity to gain experience and to acquire the necessary skills for the given position and $27.9 \%$ were evaluated positively for the vacant position regardless of their experience and level of education.

The authors believe that this kind of survey results was obtained because $39.2 \%$ of the respondents were employed and therefore did not face such a great job-finding problem, compared with the young people who were only students.

According to these survey results, the youth long-term unemployment problem is not identified so clearly because the majority of the respondents were working and living in Latvia's capital city of Riga, or had moved from the countryside to Riga.

The authors have just begun the research and will continue to identify young people in Latvian rural areas and learn their views on the mentioned issues.

The other answers mentioned were as follows:

- Most of the vacancies were created "on paper".

- Employer savings on wages by choosing a cheaper and less experienced workforce.

- Poor knowledge of the Russian language.

- I was questioned about the ability to do physical work.

- The reasons for refusal are never explained.

- The choice of a candidate with greater experience and higher education.

- I have no idea what the true attitude of employers is - I am not aware of other candidates and almost never the reasons for the refusal are widely explained, although the attitude when meeting has always been positive.

- The fact that I live close to Riga (approximately $40 \mathrm{~km}$ from Riga) is a very big problem for employers. They think that I cannot travel to work, but it is not true because there are many possibilities, for example, to use public transport.

- The year of birth and the zodiac sign were negative estimated; as a result, it became clear during a job interview that I would not get a job. And it was just because I was born in a certain year and did not have the correct zodiac sign, and my skills and abilities were not even assessed.

These cases involve discrimination and social inclusion is violated, which is determined in the national laws and international documents. According the research results, it is clearly seen that there is a need for improving the documents for unemployment regulation in Latvia and also in Europe, reducing discrimination by employers and by the responsible institutions.

Based on the results of the survey, the authors concluded that the possibilities for young people to find a job in the labour market are not as low as it is considered, and if the young person is motivated, some of employers give the possibility to prove him/herself. Another question to deal with is the ability of young people to combine work and studies as well as the proposed salary. It is positive that the employer gives the possibility for young people to get experience, and after gaining the experience, the young people have opportunities to seek a better paid job. 
Conclusions

- Young people's integration into the labour market is made more complicated in many countries of Europe.

- These allegations from young questionnaires come in conflict with the domestic law and international planning documents which stipulate the prohibition of discrimination and promote the social inclusion of young people.

- The Labour Law, the Constitution of the Republic of Latvia, the European Convention of Human Rights and other documents ensure rights and include important information on non-discriminatory treatment, fair working conditions and wages.

- The main purpose of active employment measures is to put into effect labour market policy in order to reduce unemployment and to facilitate an increase in the economic activity of inhabitants, in particular to motivate unemployed persons, to promote an increase of individuals' competitiveness, to promote equal opportunities for unemployed persons who want to enter into the labour market.

- Based on the research carried out, the authors concluded that the employers gives for young people the possibility to integrate into the labour market, if a young person is ready to prove himself, and, probably from the beginning, work for lower wages.

\section{References}

Charter of the United Nations. Retrieved: http://www.un.org/en/documents/charter/index.shtml [access: 04.10.2014].

Council Directive (In Latvian: Padomes direktīva) 2000/78/EC. (2000). Brussels. Retrieved: http://cilvektiesibas.org. lv/lv/database/padomes-direktiva-200078ec/ [access: 04.10.2014].

Convention No. 11 of the International Labour Market Organization (In Latvian: Starptautiskās darba organizācijas Konvencija Nr. 111 (Diskriminācija darba un nodarbošanās jomā). Retrieved: http://cilvektiesibas.org.lv/lv/database/starptautiskas-darba-organizacijas-konvencija-nr11/ [access: 07.10.2014].

EU Youth Strategy. Retrieved: http://ec.europa.eu/youth/policy/youth_strategy/index_en.htm [access: 11.10.2014].

European Convention of Human Rights. Retrieved: http://www.echr.coe.int/Documents/Convention_ENG.pdf [access: 27.09.2014].

Equal Treatment in Employment and Occupation (In Latvian: Vienlīdzīga attieksme pret nodarbinātību un profesiju). Retrieved: http://europa.eu/legislation_summaries/employment_and_social_policy/employment_rights_and_ work_organisation/c10823_lv.htm [access: 11.10.2014].

Framework of Actions on Youth Employment. (2013). European Social Partners, Retrieved: http://www.ueapme.com/ IMG/pdf/201306_Framework_of_Actions_Youth_Employment_final.pdf [access: 20.09.2014].

International Covenant on Civil and Political Rights. Retrieved: http://www.ohchr.org/en/professionalinterest/pages/ ccpraspx [access: 27.09.2014].

International Covenant on Economic, Social and Cultural Rights (In Latvian: Starptautiskais pakts par ekonomiskajām, sociālajām un kultūras tiesībām). Retrieved: http://www.humanrights.lv/doc/vispaar/escpakc.htm [access: 11.10.2014]

Labour Law, adopted by the Saeima on 20 June 2001, p. 1-57. Retrieved: http://www.likumi.lv/doc.php?id=26019 [access: 04.10.2014].

Draft of the National Reform Programme of Latvia for the Implementation of „Europe 2020” Strategy (In Latvian: Latvijas Nacionālais Reformu programmas „ES 2020” stratēgijas istenošanai projekts). Retrieved: http://polsis. mk.gov.lv/view.do?id=3517 [access: 07.10.2014].

National Development Plan of Latvia for 2014-2020, Cross-Sectoral Coordination Centre (CCSC). (2012). Retrieved: http://www.pkc.gov.lv/images/NAP2020\%20dokumenti/NDP2020_English_Final.pdf [access: 11.10.2014].

Support for Unemployed Persons and Persons Seeking Employment (In Latvian: Bezdarbnieku un darba meklètāju atbalsta likums). The Law has been adopted by the Saeima, 9 May 2002, p. 1-16.

Constitution of the Republic of Latvia. Retrieved: http://www.saeima.lv/en/legislation/constitution [access: 04.10.2014].

Labour Law with the Comments (2010) (In Latvian: Darba likums ar komentāriem). Free Trade Union. Attorneys at Law „BDO Zelmenis \& Liberte”. Retrieved: http://www.lbas.lv/upload/stuff/201102/dl_ar_kom.pdf [access: 04.10.2014].

United Nations Human Rights Convention (In Latvian: Cilvēktiesību un pamatbrīivību aizsardzības konvencija. Retrieved: http://www.humanrights.lv/doc/regional/eckkons.htm [access: 20.09.2014]. 
International Contracts of the Republic of Latvia (In Latvian: Par Latvijas Starptautiskajiem līgumiem). Retrieved: http://likumi.lv/doc.php?id=57840 [access: 20.09.2014].

European Social Charter (In Latvian: Eiropas sociālā harta). Retrieved: http://www.likumi.lv/doc.php?id=56660 [access: 07.10.2014].

Specific Problems of the Labour Market in Latvia and its Regions (In Latvian: Latvijas un tās regionu darba tirgus specifiskās problēmas). Retrieved: http://www.va.lv/sites/default/files/regiona darba tirgus.pdf [access: 07.10.2014].

Universal Declaration of Human Rights (In Latvian: Vispārējā cilvēktiesību deklarācija). Retrieved: http://www.humanrights.lv/doc/vispaar/vispcd.htm [access: 11.10.2014].

Acknowledgements

The preparation of the paper was supported by the National Research Program 5.2. Economic Transformation, Smart Growth, Governance and Legal Framework for the State and Society for Sustainable Development-a New Approach to the Creation of a Sustainable Learning Community, Project EKOSOC_LV.

\section{ISTATYMINE JAUNIMO NEDARBO IR VERSLUMO REGULIAVIMO BAZE் LATVIJOJE}

LĪVA GRIN̦Eviča, BaIBA RivŽA

Latvijos žemès ūkio universitetas (Latvija)

\section{Santrauka}

Jaunimo nedarbas, ypač ilgalaikis, yra viena didžiausių problemų Europoje, kurią būtina spręsti. Vis tebesitęsiant ekonominei ir finansinei krizei, jaunimo galimybès ịsidarbinti yra mažesnès negu bet kurios kitos visuomenės grupės narių. Taigi jauni žmonės susiduria su socialinėmis problemomis, kurių negali išspręsti, neịsitraukę ị darbo rinką. Tai lemia ateities nestabilumą. Straipsnyje analizuojami ịstatyminiai ir instituciniai jaunimo nedarbo ir socialinès integracijos klausimų sprendimo dokumentai. Aptariamos diskusijos analizuojamu klausimu. Straipsnyje pateikti tyrimo duomenys apie jaunų žmonių integraciją i darbo rinką. Svarbu akcentuoti šių dokumentų svarbą, ịvertinant jaunimo nedarbo reguliavimą ir nedarbo mažèjimo planavimą.

PAGRINDINIAI ŽODŽIAI: jaunimo integracija, jaunimo nedarbas, įstatymine jaunimo nedarbo bazé.

JEL KLASIFIKACIJA: E24, J64 